\title{
THE EFFECT OF THE QUANTITY AND QUALITY OF MILK REPLACER INTAKE ON STARTER FEED INTAKE IN HOLSTEIN CALVES
}

\author{
Sz. Tóth \\ tothszandra8@gmail.com
}

Kaposvár University, Faculty of Agricultural and Environmental Sciences, Guba Sándor út., 40, Kaposvár, H-7400, Hungary

The aim of this study was to evaluate the effects of increasing amounts and quality of liquid feed of calves on starter feed intake in real farm situations.

Three calf rearing system were compared. We offered different type and amount of solids content of liquid feed by using whole milk and two different milk replacer (MR). The dry matter intake in group $A, B$ and $C$ were accordingly 898; 1033; $1050 \mathrm{~g} /$ calf/day. In group A whole milk and MR1 were used, instead of group $B$ and $C$ where MR 1 or MR2 were used exclusively. The MRs differed in CP level (21\% vs. $27 \%)$, in proportion of palm/coconut oil (80/20; 60/40) and in technology of production (spray drying vs. spray cooling).

The statistical analyses shown strong connection between the amount and quality of milk replacer intake and starter feed intake $(P<0.001)$ before, under and after the weaning period. Between week 2 and 7 the calves in group C ate three times more starter than members of group A and B (129 g/day; $135 \mathrm{~g} /$ day; $464 \mathrm{~g} /$ day). This difference remained significant later on too. The data of group $B$ differs significantly $(P<0.05)$ only the $9^{\text {th }}$ week of life from group $A$. The feeding systems also effect changes in $B W(P<0.01)$ and $A D G(P<0.001)$.

Keywords: CALVES, FEED INTAKE, MILK REPLACER QUALITY, FEED INTENSITY, DRY MATTER INTAKE

Creating the conditions necessary for a successful early weaning is an especially important criterion in calf nutrition. To meet this objective, the development of the rumen must be supported by the use of appropriate technologies. Before weaning, the calf must be able to successfully prepare for the intake of adequate amounts of dry matter and should have a sufficiently mature rumen to allow the efficient utilisation of feed. If the calf is weaned before it meets the above conditions, this inevitably results in lower performance and slower body weight gain [3]. According to many research and farm practices, the conventional feeding programs cause a higher starter feed intake in dairy calves. $[1,2,5,7]$ report about the disadvantages of providing more milk or milk replacer include reduced solid feed intake during the milk-feeding period. After research of [4], the increase in calves' weight gain has come to the fore. If we focus on the development of rumen only in the week of choice, we increase the incidence of health problems caused by choice. A smooth transition from liquid feed (milk or milk replacer) to solid feed (grains or forage) is important in minimizing weight loss and distress at weaning [6].
According to the challenge of the age, we need to find solutions for calf rearing that provide high growth strength and high starter feed intake at the same time. We want to contribute to this problem solving with the data measured by us in working farm situations.

\section{Materials and methods}

Experimental animals and housing. We compared data measured under different liquid feeding system in calf rearing on a HF dairy farm (1800 cows). 30, 45 and 20 HF heifers were used in the three different groups (A, B, C). The calves received 3.5 litres of colostrum via an oesophageal tube within 2 hours of birth. 12 to 24 hours after birth, the calves were transferred from the calving barn to the calf rearing unit, where they were placed in individual straw bedding calf hutches (Calf-Tel Pro II, Hampel Corporation, Germantown, Wisconsin, USA) in the order of their birth.

Feeding. The calves received liquid feed twice a day from bucket at 12 hours intervals. All of the groups we used the same feeding and weaning method: increased the amount of liquid in the first weeks (A and B for 3 weeks, C only for 1 week), 
The liquid feeding systems in groups

\begin{tabular}{|c|c|c|c|}
\hline & A & $\mathrm{B}$ & $\mathrm{C}$ \\
\hline Base of the liquid feed & $1 / 3$ whole milk $+2 / 3 \mathrm{MR} 1$ & MR1 & MR2 \\
\hline $\mathrm{CP} / \mathrm{Fat}$ content in $\mathrm{MR}$ & $21 / 17$ & $21 / 17$ & $27 / 17$ \\
\hline Dilution ratio & $12,5 \%$ & $14,5 \%$ & $14 \%$ \\
\hline Average solid feed intake from liquid, g/calf/day & 898 & 1033 & 1050 \\
\hline Palm oil / coconut oil ratio, $\%$ & $80 / 20$ & $80 / 20$ & $60 / 40$ \\
\hline Technology of production & spray drying & spray drying & spray cooling \\
\hline
\end{tabular}

then we decreased the amount of liquid on the $8^{\text {th }}$ week of life and we finished the liquid nutrition at the start of week 9. In group A from day 1 to day 21 only MR1 were used and after 21 day we fed with a mix of $2 / 3 \mathrm{MR} 1$ and $1 / 3$ whole pasteurized milk. In group $\mathrm{B}$ and $\mathrm{C}$ we used only MR in whole experimental period and we used a higher dilution ratio, to compare the effects of the dry matter intake from liquid feeding. The main components of both milk replacers were whey powder and $15 \%$ skimmed milk powder but they differ in CP level, in proportion of palm/coconut oil. They also differs in technology of production, which can modify the digestibility of the ingredients. The MR1 (Sprayfow Yellow, Trouw Nutrition, Sloten, The Netherlands) were made with spray drying system, where the added fat forms a uniform coating around the protein. The MR2 (Nukamel Performer, Weert, The Netherlands) were made with spray cooling system, which means the added fat forms a crosslinked structure around the protein, making it easier to digest. The differences between the liquid feeding systems in the study are shown in table 1.

Drinking water was available from the first day, while calf starter from day 7 ad libitum. The nutrient content of starter diets (UBM Feed Ltd., Hungary) is shown in table 2.

Samplings and measured parameters. Individual starter feed intake was recorded for all animals every day. For ease of comparison, the feed intake was averaged weekly for each group. All calves were measured after the birth. Since the data of the 3 groups here are from 3 different experiments, the times of weight measurements
Nutrient content of starter diets, \% (as specified by the manufacturer)

Table 2

\begin{tabular}{|l|c|}
\hline \multicolumn{1}{|c|}{ Nutrient content, \% } & \\
\hline Moisture & 11.19 \\
\hline Dry matter & 88.81 \\
\hline Crude protein & 20.19 \\
\hline Crude oils and fats & 4.49 \\
\hline Crude fibre & 10.40 \\
\hline Crude ash & 6.44 \\
\hline Total sugar & 8.01 \\
\hline Starch content & 14.22 \\
\hline NDF & 32.41 \\
\hline ADF & 14.26 \\
\hline N-free extract & 45.50 \\
\hline NEm, MJ/kg & 7.43 \\
\hline NEg, MJ/kg & 4.84 \\
\hline
\end{tabular}

are not the same in the groups. Group A was measured after one week of the weaning, while calves from group $\mathrm{C}$ when we finished the liquid feed. The time in days of the last weight measured is seen in table 3 in the results section.

Statistical analyses. Statistical analysis was done using the $R$ Commander 3.4.1 program type (Free Software Foundation Inc., 1991). OneWay ANOVA and Kruskal-Wallis procedures of the programme were use for analysing and compare the variances. Differences were considered as significant if $\mathrm{P}<0.05$.

\section{Results and discussion}

Starter feed intake. The fig. 1 shows the feed intake of the groups. The statistical analyses shown strong connection between the amount and quality of liquid feed and starter feed intake

Body weight and average daily gain in groups

Table 3

\begin{tabular}{|l|c|c|c|c|c|c|c|c|c|}
\hline & \multicolumn{3}{|c|}{ Groups } & \multicolumn{5}{c|}{ Statistical analyses } \\
\hline & A & B & C & P & SEM & CV & A-B & B-C & A-C \\
\hline Weight at birth, kg & $39 \pm 3$ & $38 \pm 4$ & $39 \pm 4$ & & 0.37 & 0.09 & & & \\
\hline Weight at end, kg & $74 \pm 7$ & $77 \pm 7$ & $81 \pm 7$ & $<0.01$ & 0.76 & 0.09 & & 0.07 & $<0.01$ \\
\hline ADG & $550 \pm 93$ & $624 \pm 106$ & $769 \pm 99$ & $<0.001$ & 13.36 & 0.20 & $<0.01$ & $<0.001$ & $<0.001$ \\
\hline Age of measure, day & 64 & 60 & 56 & & & & & & \\
\hline
\end{tabular}




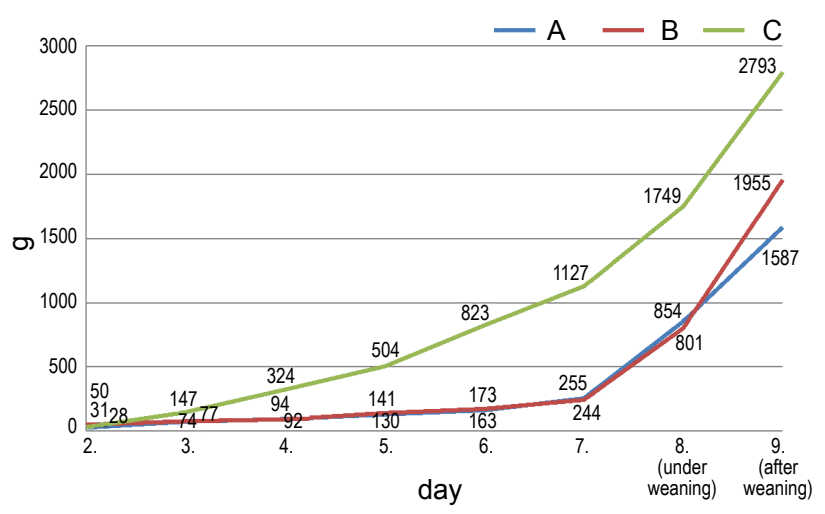

Fig. Feed intake of the groups

$(\mathrm{P}<0.001)$ before, under and after the weaning period. Except the $2^{\text {nd }}$ weeks of life, the starter feed intake of group $\mathrm{C}$ was significant higher $(\mathrm{P}<0.001)$ than other groups. The data of group $\mathrm{B}$ differs significantly $(\mathrm{P}<0.05)$ only the $9^{\text {th }}$ week of life from group A.

To compare the line of A with B, it can be stated that higher intake of dry matter may increase the starter feed intake after stopping liquid feeding, but has no effect on the consumption during the drinking time. This can be explained by the increased body weight caused by more intense nutrient supply and thus by the greater need for it. To compare the line of B with $\mathrm{C}$, it can be seen that, with the same dry matter intake, the milk replacer that has a better digestibility due to its production technology increases the uptake of the starter feed even at higher protein intake. If we think about the rumen development as one of the most determinative thing in the calves rearing, the consistent starter feed intake like in group $\mathrm{C}$ is more favorable. In group A and B only one week is available for the rumen to prepare for that amount of starter feed which can be supply the life and growth needs without the nutrients which came from the liquid feeding.

Body weight, daily weight gain. Regardless of the measurement at different times, the difference between the groups is clearly visible in table 3. Nowadays, the basic goal of calf rearing is to double the birth weight by the time of the weaning. Due to the higher protein level and better digestibility the group $\mathrm{C}$ reach higher $\mathrm{ADG}$ and BW in less time than group B, altough they got the same solid feed intake from MR.

\section{Conclusions}

According to our data, the digestibility and composition of the milk replacer have an effect on preweaning starter feed intake. The increased daily gain due to the higher protein and dry matter intake from milk replacer, can effect on starter feed intake under and after the weaning period. Creating the conditions necessary for a successful early weaning is an especially important criterion in calf nutrition. To meet this objective, the development of the rumen must be supported by the use of appropriate technologies.

1. Azevedo R. A., Marchado F. S., Campos M. M., Lopes D. R. G., Costa S. F., Mantovani H. C., Lopes F. C. F., Marcondes M. I., Pereira L. G. R., Tomich T. R., Coelho S. G. The effects of increasing amounts of milk replacer powder added to whole milk on passage rate, nutrient digestibility, ruminal development and body composition in dairy calves. Jornal of Dairy Science, 2016, vol. 99, issue 11, pp. 8746-8758. DOI: $10.3168 /$ jds.2016-11410.

2. Khan M.A., Weary D. M., Keyserlingk vonM.A.G. Invited review: Effect of milk ration on solid feed intake, weaning, and performance in dairy heifers. Journal of Dairy Science, 2010, vol. 94, issue 3, pp. 1071-1081. DOI: 10.3168/jds.2010-3733.

3. Klein R. D., Kincaid R. L., Hodgson A. S., Harrison J. H., Hillers J. K., Cronrath J. D. Dietary fiber and early weaning on growth and rumen development of calves. Journal of Dairy Science, 1987, vol. 70, issue 10, pp. 2095-2104. DOI: 10.3168/jds.S00220302(87)80259-X.

4. Moallem U., Werner D., Lehrer H., Zachut M., Livshitz L., Yakoby S., Shamay A. Long-term effects of ad libitum whole milk prior to weaning and prepubertal protein supplementation on skeletal growth rate and first-lactation milk production. Journal of Dairy Science, 2010, vol. 93, issue 6, pp. 2639-2650. DOI: 10.3168/jds.2009-3007.

5. Terré M., Devant M., Bach A. Effect of level of milk replacer fed to Holstein calves on performance during the preweaning period and starter digestibilit at weaning. Livestock Science, 2007, vol 110, issue 1-2, pp. 82-88. DOI: 10.1016/j.livsci.2006.10.001.

6. Weary D. M., Huzzey J. M., Keyserlingk vonM.A.G. Board-invited review: Using behavior to predict and identify ill health in animals. Journal of Animal Science, 2009, vol. 87, issue 2, pp. 770-777. DOI: 10.2527/jas.2008-1297.

7. Weary D. M., Jasper J., Hötzel M. J. Understanding weaning distress. Applied Animal Behavior Science, 2008, vol. 110, issue 1-2, pp. 24-41. DOI: 10.1016/j.applanim.2007.03.025. 